Volume 5 Nomor 1, Februari 2020, halaman 87-100

\title{
INTEGRASI TEKNOLOGI DALAM PENGAJARAN MATEMATIKA
}

\section{INTEGRATION OF TECHNOLOGY IN TEACHING MATH}

\author{
Neneng Aminah ${ }^{1}$, S.B. Waluya ${ }^{2}, \operatorname{Rochmad}^{3}$ \\ ${ }^{1}$ Universitas Swadaya Gunung Jati, Jalan Perjuangan No 1 Cirebon, Indonesia. \\ ${ }^{2,3}$ Universitas Negeri Semarang, Jalan Kelud Raya Semarang, Indonesia \\ Email: nenengaminah255@gmail.com, sbwaluya.mail@unnes.com, \\ rachmadmanden.mail@unnes.com
}

\begin{abstract}
ABSTRAK
Pesatnya perkembangan teknologi, dapat berdampak pada semua bidang, bidang pendidikan termasuk didalamnya, fasilitas yang belum memadai merupakan salah satu problematika guru dalam mengajar, sedangkan guru dituntut untuk mengikuti perkembangan jaman. Guru merupakan pendidik yang harus memiliki berbagai kemampuan, bukan hanya materi saja yang harus dimiliki namun mereka harus memiliki kemampuan untuk mengajar, dengan pesatnya perkembangan jaman, hal ini berpengaruh pula pada bidang pendidikan, salah satunya pada pengajaran di kelas, sudah hampir seratus persen siswa pasti mengenal dengan gadgetnya, maka seorang guru diharapkan bisa memanfaatkan keadaan ini untuk pembelajaran di kelas. Hal ini merupakan sebuah problematika yang terjadi dikalangan pengajar, walaupun tidak semua guru mengalami hal ini, metode penelitian yang digunakan adalah kualitatif, peneliti melakukan studi literatur, dimana data hasil litelatur akan dijadikan sumber untuk membuat intrumen penelitian lanjutan, hasilnya bahwa pengusaan teknologi dalam pembelajaran matematika, di jaman sekarang guru profesional di tuntut untuk menguasai kemampuan mengajar, kemampuan materi, yang terintegrasi ke dalam kemampuan teknologi, dimana para ahli pendidikan menyebutnya dengan kemampuan Technologi Pedagogic and Content Knowledge (TPACK), karena pengetahuan ini mensinyalir dapat meningkatkan profesionalisme guru.
\end{abstract}

Kata Kunci: Integrasi Teknologi, TPACK, Studi literatur

\section{ABSTRACT}

The rapid development of technology, can have an impact on all fields, including education, inadequate facilities is one of the problems of teachers in teaching, while teachers are required to follow the changing times. Teachers are educators who must have various abilities, not only material that must be possessed, but they must have the ability to teach, with the rapid development of the 
era, this also affects the field of education, one of them in teaching in the classroom, almost one hundred percent of students certainly familiar with the gadget, then a teacher is expected to be able to take advantage of this situation for learning in the classroom. This is a problem that occurs among teachers, although not all teachers experience this, the research method used is qualitative, researchers conduct a study of literature, where data on the results of literature will be used as a source for making further research instruments, the result is that the adoption of technology in mathematics learning During the Industrial Revolution 4.0 era, professional teachers were demanded to master teaching abilities, material abilities, which were integrated into technological capabilities, which educational experts called the Pedagogic and Content Knowledge (TPACK) capability, because this knowledge was supposed to increase teacher professionalism.

Keywords: technology integration, TPACK, literature study

How to Cite: Aminah, N., Waluya, S. B., Rochmad. (2020). Integrasi Teknologi Dalam Pengajaran Matematika. Mathline: Jurnal Matematika dan Pendidikan Matematika, Vol.5 No.1, 87-100

DOI: https://doi.org/10.31943/mathline.v5i1.122

\section{PENDAHULUAN}

Perkembangan teknologi semakin meningkat hal ini berdampak di segala bidang, dengan keadaan seperti ini menuntut sumber daya manusia mengikuti perkembangan jaman, begitu pula dibidang pendidikan, harus mampu memilah hal yang baik demi lahirnya para penerus bangsa, dibidang pendidikan semua pihak diantaranya selain orang tua, masyarakat, tentunya guru harus mampu membimbing keadaan seperti ini ke dalam pembelajaran. Terlebih lagi guru sebagai pusat pembelajaran di sekolah, dengan berkembangnya teknologi banyak sekali kelemahan dan kelebihannya, salah satu kelemahannya teknologi tidak dapat memberikan sentuhan kasih sayang seorang guru maupun orang tua yang diperlukan pada kegiatan pembelajaran. Oleh karena itu seorang guru di tuntut untuk memiliki kemampuan mengajar, dan kemampuan materi.

Shulman mengungkapkan perpaduan antara pengetahuan dalam cara mengajar yang tepat di sebut sebagai pengetahuan konten pedagogik (Pedagogical Content Knowledge) (Aminah \& Wahyuni, 2018), terlebih lagi sekarang ini ternyata guru pun di tuntut untuk memiliki kemampuan teknologi. Sejalan dengan hasil penelitian (Niess, 2008a; Niess, 2008b; Thomson \& Mishra, 2007) dikatakan Technologi Pedagogic and Content Knowledge (TPACK) sebagai konstruksi dinamis yang menggambarkan pengetahuan yang dibutuhkan oleh guru ketika mendesain, menerapkan kurikulum, pengajaran dengan membimbing siswa dalam belajar dengan teknologi digital. 
Hasil penelitian Aminah dan Wahyuni, (2018) juga melaporkan bahwa mahasiswa pada program studi matematika masih jarang menggunakan digital dalam melakukan praktek mengajar, ternyata dampak adanya teknologi dari sebagian kalangan menjadi sebuah problematika. Hal ini juga sesuai dengan hasil wawancara yang telah dilakukan oleh penulis tentang sejauh mana guru matematika SMP mengetahui tentang TPACK, ternyata hasil dari wawancara tersebut dari beberapa guru yang di minta keterangan pemahaman arti dari TPACK hanya 10\% yang mampu menjawab dengan baik.

\section{METODE PENELITIAN}

Penelitian ini menggunakan penelitian kualitatif, yaitu dengan mengumpulkan karya tulis ilmiah, yang sesuai dengan objek yang akan di teliti, atau menelaah secara mendalam terhadap pustaka yang relevan, untuk memecahkan suatu masalah. Penelitian ini bersifat penelitian deskripstif, dimana penelitian berfokus di penjelasan secara sistematik. Temuan yang dihasilkan akan menjadi bahan acuan penelitian berikutnya

\section{HASIL DAN PEMBAHASAN}

\section{Pembelajaran Menggunakan Teknologi}

Teknologi Informasi dan Komunikasi (TIK) memiliki posisi yang sangat penting dalam mencapai tujuan pendidikan menurut Ministry of Education and Culture (2010), hal ini mengharuskan semua warga sekolah yaitu para semua staf dan anggota sekolah bersamasama untuk berkomitmen pada TIK (Jimoyiannis, A. \& Komis, V., 2007). Melalui TIK baik dibidang pendidikan maupun kesehatan dapat berbagi informasi. Dengan adanya technology hal ini tentu ada kelebihan dan kekurangannya, untuk kelebihan pembelajaran berbasis ICT ini antara lain menghemat waktu dalam kegiatan belajar, karena tidak memerlukan perjalanan, pembelajaran bisa dilakukan dimana saja (Korhonen, T., \& Lammintakanen, J. 2005). Kerugian pembelajaran ICT diantaranya menghabiskan dana untuk komponen komupter serta pemeliharannya, persiapan siswa yang kurang memadai dalam pembelajaran berbasis ICT, pembelajaran tidak realistis, hal ini diperkuat dari hasil penelitian yang telah dilakukan oleh Attack (2003) menunjukan bahwa siswa sering mengalami kesulitan saat diberikan dengan metode web hal ini dikarenakan kurang memadai sarana online. Hal ini merupakan problematika pembelajaran yang terjadi di sekitar kita.

Gambaran problematika guru terhadap teknologi, salah satunya dapat dilihat berdasarkan hasil penelitian yang dilakukan oleh Supangat, Amna, \& Sulistiawati (2018) 
terkait kemampuan guru terhadap teknologi pada salah satu wilayah di Surabaya, melaporkan bahwa kebanyakan guru sudah mengenal konsep E-learning, tetapi perangkat yang digunakan masih sangat terbatas pada power point, sedangkan perangkat aplikasi pembelajaran lainnya masih jarang digunakan bahkan perangkat aplikasi etmodo, schoology misalnya tidak pernah digunakan, untuk teknologi masih sebatas email google.

Penelitian yang dilakukan oleh Syukur A.I. (2014) ini bertujuan untuk mengkaji persepsi guru SD, SMP, SMA dan SMK terhadap profesionalisme guru saat mengimplementasikan Teknologi dalam meningkatkan kualitas belajar mengajar, hasilnya menunjukan bahwa ,75\% guru SD, SMP, SMA, dan SMK mengatakan sangat jarang mempergunakan laptop untuk mengajar, selain itu penelitian ini mengkaji lebih dalam apa saja kendala yang terjadi pada guru saat mengimplementasikan teknologi dala meningkatkan kualitasnya. Hasilnya 34,95\% guru SD, SMP, dan SMA mereka kurang menguasai teknologi, sedangkan 10,03\% guru SMK menyatakan bahwa mereka mampu namun sarana dan prasarana disekolah yang kurang mendukung dalam pembelajaran menggunakan teknologi.

Penelitian tersebut, memiliki persamaan dari kendala yang dihadapi guru yaitu selain kurangnya mendapatkan pelatihan, hal ini juga karena kurangnya sarana dan prasarana penunjang. Guru juga kurang memahami pengetahuan pedagogic dan konten yang terintegrasi dengan teknologi, hal ini juga menjadi perhatian khusus dikalangan universitas yang melahirkan calon guru, untuk itu pada makalah ini juga perlu dibahas terkait kemampuan TPACK yang mensinyalir akan mengurangi problematika guru yang kurang paham tentang teknologi. Secara internasional, sebuah penelitian telah menunjukkan bahwa siswa lebih banyak belajar matematika dan mempelajarinya lebih dalam dengan menggunakan teknologi secara efektif dan tepat selama mengajar dan belajar matematika termasuk beberapa studi menunjukkan penutupan kesenjangan prestasi yang kurang terwakili oleh siswa (Barkatsas, Kasimatik, \& Gialamas, 2009; Bos, 2007; Doerr \& Zangor, 2000; Duda, 2011).

Pada beberapa studi telah menunjukkan sangat sedikit bahkan tidak ada efek pencapaian yang spesifik untuk integrasi teknologi ke dalam kelas matematika (Torff \& Tirotta, 2010). Faktor yang membedakan antara temuan penelitian secara mendasar didasarkan pada bagaimana teknologi digunakan secara pedagogis oleh guru, keyakinan mereka tentang teknologi, dan apakah siswa menggunakan perangkat untuk membuat koneksi matematika dan bagaimana mengecek bahwa matematika dipahami bukan hanya untuk perhitungan saja. Menurut litelature implementasi teknologi guru yang efektif dalam 
kelas matematika sangat lambat, karena berbagai alasan yaitu: (a) penolakan terhadap perubahan, (b) kurangnya kepercayaan diri, (c) akses, (d) kegunaan, (e) ketakutan (mis., kegagalan teknis, siswa mengetahui lebih banyak tentang teknologi dari pada guru), dan (f) inhibitor (Pierce \& Ball, 2009).

Guru matematika kini banyak menyadari peluang teknologi yang baik untuk pembelajaran, seperti teknologi yang ada saat ini yaitu papan tulis interaktif, kalkulator grafis, dinamis software matematika, program grafis, computer sistem aljabar dan lain-lain, juga digunakan untuk belajar (Tanujaya, dkk; Faturahman, dkk. 2017). Namun, kualitas penggunaan teknologi tidak hanya menggunakan teknologi itu sendiri tapi bagaimana teknologi yang dipilih dapat diintegrasikan ke dalam konten tertentu dalam belajar. Seorang guru dengan pengetahuan TPACK diasumsikan untuk dapat mengetahui bagaimana untuk mengintegrasikan teknologi ke dalam konten yang spesifik dan dapat menerapkan pedagogi yang paling tepat untuk mengajar (Muhtadi, dkk. 2017)

\section{Technology Pedagogical and Content Knowledge (TPACK)}

Pembelajaran dengan teknologi seorang guru tidak cukup hanya dengan memiliki keterampilan komputer yang baik saja, namun seorang guru harus dapat mendesain pembelajaran yang akan disajikan dengan kemampuan konten dan pedagogi. Beberapa penelitian menunjukan bahwa guru yang memiliki ketrampilan komputer yang baik dengan mengikuti pelatihan khusus dalam penggunaan komputer, mereka memiliki pengetahuan yang baik pula dalam merancang pembelajaran berbantuan komputer, daripada guru yang memiliki keterampilan teknis yang baik namun tidak dibekali pelatihan khusus dalam penggunaan komputer, (Angeli, C., \& Valanides, N. 2005). Mereka menyimpulkan bahwa kegiatan pelatihan guru tentang interaksi antar teknologi, konten dan pedagogi harus dilakukan secara ekplisit hal ini untuk mengetahui kemampuan guru dalam mengembangkan kemampuan TPACK dalam mengenali, menggambarkan dan menggunakan teori belajar.

Technology Pedagogy and Content Knowledge (TPACK) menitikberatkan pada koneksi dan interaksi antara konten, pedagogi, dan teknologi (Mishra\&Kohrer, 2006). TPACK digambarkan sebagai suau paket pengetahuan guru secara total yang diperlukan untuk mengintegrasikan teknologi, pedagogi, dan pengetahuan konten dalam suatu desai kurikulum dan instruksi (Niess, et.all, 2009; Thomson \& Mishra, 2007) TPACK merupakan pengetahuan baru dalam pemahaman interaksi yang komplek antara konten, pedagogi, dan teknologi yang menghasilkan keberhasilan integrasi teknologi di dalam kelas. TPACK merupakan suau kemampuan yang harus dikuasai setelah mengeuasi PCK, dimana ketika 
guru harus memiliki pengetahuan bagaiman caranya dapat mengubah strategi pedagogis dan representasi konten dengan menggunakan teknologi. Mishra\&Kohrer, (2006) menyatakan bahwa TPACK adalah bentuk pengetahuan yang dibutuhkan untuk menggunaan teknologi secara cerdas dalam kegiatan belajar mengajar di kelas.

Chai et al. (2013) mengklaim bahwa kerangka kerja TPACK mengarahkan para peneliti dan pendidik pada komponen yang diperlukan untuk pengajaran dengan teknologi untuk mengatasi kesulitan guru dalam mengintegrasikan teknologi dalam pengajaran mereka. Dalam beberapa tahun terakhir, kerangka TPACK sangat menerima perhatian besar, menurut kerangka kerja ini, seorang guru tidak hanya cukup memiliki pengetahuan pedagogic dan konten saja, melainkan harus dapat menintegrasikan pengetahuan teknologi kedalam pengajaran. Inti dari pengajaran TPACK memiliki tiga kompoonen yang penting yaitu, konten, padagogi, dan teknologi, yang ketiganya saling mempengaruhi satu sama lainnya. (Mishra \& Kohrer, 2006). Berikut merupakan gambar kerangka kerja TPACK.

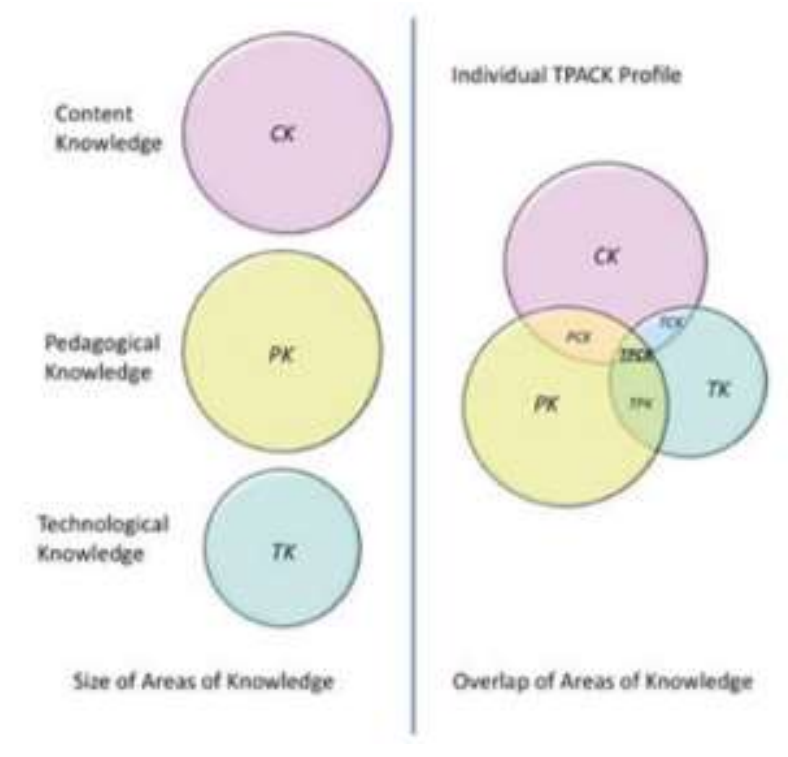

Gambar 1. Individual instructor TPACK profiles

(S.N. Kushner Benson et al., 2015)

Seperti yang ditunjukan pada gambar 1, kerangka kerja TPACK menurut Mishra dan Koehler (S.N. Kushner Benson et al., 2015) berisi tiga pilar; (1) pengetahuan konten yaitu tentang materi pelajaran yang akan diajarkan, dalam hal ini peneliti akan lebih mendalami dan mengkaji terkait pembelajaran matematika, (2) pengetahuan pedagogis yaitu tentang pengetahuan proses belajar mengajar, pada pilar kedua ini peneliti akan lebih dalam mempelajari teori belajar yang mengarah pada pembelajaran matematika, dan pilar terakhir yaitu (3) pengetahuan teknologi yaitu tentang pengetahuan guru menggunakan teknologi 
dalam mengajar misalnya menggunakan media dengan teknologi, memberikan evaluasi berbantuan computer, bahkan membuat lingkungan belajar secara online dan interaktif. Tiga pilar ini diintegrasikan untuk membentuk empat basis pengetahuan: (1) pengetahuan konten pedagogis (PCK) tentang bagaimana metode yang cocok digunakan untuk materi pembelajaran tertentu, (2) pengetahuan pedagogis teknologi (TPK) tentang teknologi yang sesuai dengan metode pengajaran, (3) pengetahuan konten teknologi (TCK) yaitu cara menyelaraskan teknologi dengan konten pembelajaran, dan (4) pengetahuan teknologi, pedagogis dan konten (TPACK) tentang kombinasi teknik, konten, dan pedagogi. (Voogt , et. all, 2016).

TPACK mulai banyak diteliti pada tahun 2005 yang semula disingkat dengan TPCK seiring waktu berganti menjadi TPACK (Chai, Koh, \& Tsai, 2013). TPACK merupakan Pedagogical Content Knowledge (PCK)-nya Shulman (1986) yang telah dikembangkan. TPACK merupakan sebuah kerangka mengajar yang mengintegrasikan teknologi (Koehler, Mishra, Ackaoglu,\&Rosenberg, 2013). Tiga pilar yang telah dibahas diatas, kerangka kerja TPACK terintegrasi menjadi beberapa domain yang akan dijelaskan sebagai berikut. TPACK kemampuan guru dapat dicapai bila guru tahu: (a) bagaimana alat teknologi dapat mengubah strategi pedagogis dan representasi dari konten untuk mengajar topik tertentu, dan (b) bagaimana alat teknologi dan dampak pada pemahaman representasi siswa terhadap topik (Graham, et.al. 2009)

Technological Knowledge (TK) merupakan domain pertama yang tentang pemahaman guru dalam mengoperasikan software dan hardware komputer, sarana untuk presentasi seperti power point, dan teknologi lainnya yang terkait dengan pembelajaran. Salah satu temuan yang paling terus-menerus dicatat mengenai variasi pedagogis dengan penggunaan komputer berkaitan dengan fakta bahwa perangkat lunak konstruktivis berpotensi membuka interaksi kolaboratif antara siswa dan akibatnya, berdampak pada pembagian kerja dalam kelas, lingkungan berbasis komputer membuka ruang bagi siswa untuk bekerjasama dalam rangka memecahkan masalah dan bekerja secara kolaboratif.(Hardman, J, 2015). Gambar 1 merupakan contoh berbagai teknologi yang perlu diketahui oleh para guru. 


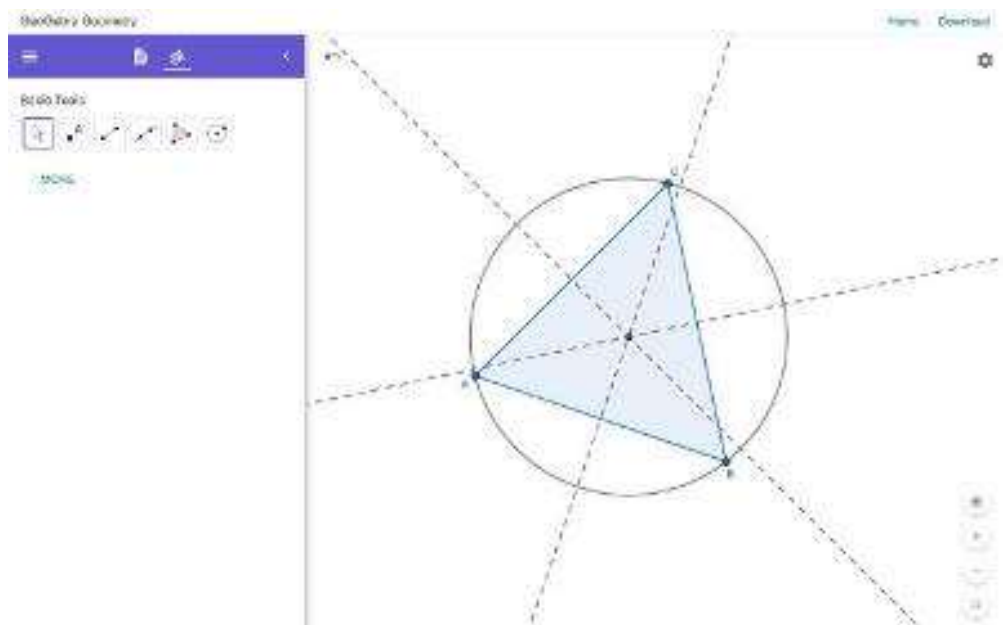

Gambar 1: Tampilan Software Gogebra

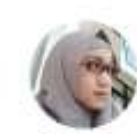

Account

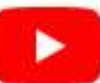

YouTube

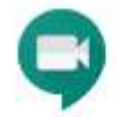

Meet

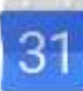

Calendar

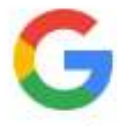

Search

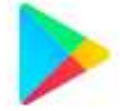

Play

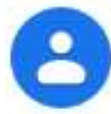

Contacts

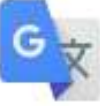

Translate

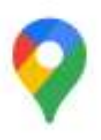

Maps

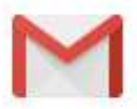

Gmail

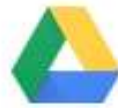

Drive

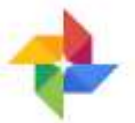

Photos

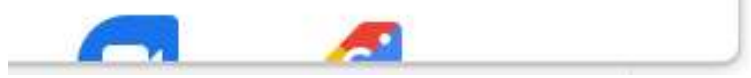

Gambar 2: contoh fitur yang dimiliki oleh google

Content Knowledge (CK) pengetahuan ini lebih mengarahkan guru kepada kekhususan sebuah disiplin ilmu materi pelajaran. Pengetahuan ini pastilah berbeda di tiap jenjang tingkatannya. Seorang guru sangat diharapkan untuk menguasai kemampuan ini, kajian ini telah di tulis oleh beberapa peneliti seperti Jason (2011), A. Tzavara \& V Komis (2015). Kemampuan ini juga penting karena menentukan cara kekhasan berpikir dari setiap kajian disiplin ilmu, misalnya kemampuan matematika, seorang guru harus mampu 
dan paham akan indikator dari beberapa kemampuan matematis yang akan diajarkannya. Seperti yang didefinisikan oleh Kilpatrick et al. kemampuan matematika membutuhkan beberapa kemampuan yang saling berpengaruh satu dengan yang lainnya yaitu pemahaman konseptual, kompetisi startegis, penalaran, kelancaran prosedur, serta disposisi" (Aminah, N. 2018).

Pedagogical Knowledge merupakan kemampuan yang harus dimiliki guru dalam mendeskripsikan tujuan umum untuk kekhasan pengetahuan saat mengajar. Pada kemampuan ini guru diasah untuk dapat mengembangkan keterampilan dalam mengelola, mengorganisasi, aktivitas pembelajaran untuk mencapai tujuan pembelajaran yang diharapkan, serta pembelajaran menjadi kondusif, hal ini telah di teliti oleh Jaiman dkk (2018).

Pedagogical Content Knowledge merupakan pengetahuan tentang pedagogi, dalam praktik mengajar di kelas, dan proses membuat perencanaan yang berlaku dan sesuai untuk mengajar suatu mata pelajaran tertentu, dalam hal ini guru matematika, maka akan di pacu untuk dapat membuat rencana pengajaran sesuai dengan materi yang akan diajarkan, mana metode yang cocok, strategi, bahkan alat atau media yang sebaiknya digunakan untuk materi tersebut (Abbit, 2015). Salah satu contoh jika guru akan mengajarkan materi geometri, harus memikirkan misalnya menggunakan software geogebra. Kemampuan ini lebih kepada pemahaman kekhasan saling mempengaruhinya konten dan pedagogi, pada saat ini kemampuan guru dalam membuat RPP menuangkan pemahaman tentang konten dengan pedagogic, gambar 3 merupakan contoh membuat RPP satu halaman yang seyogyanya juga dipelajari oleh para guru.

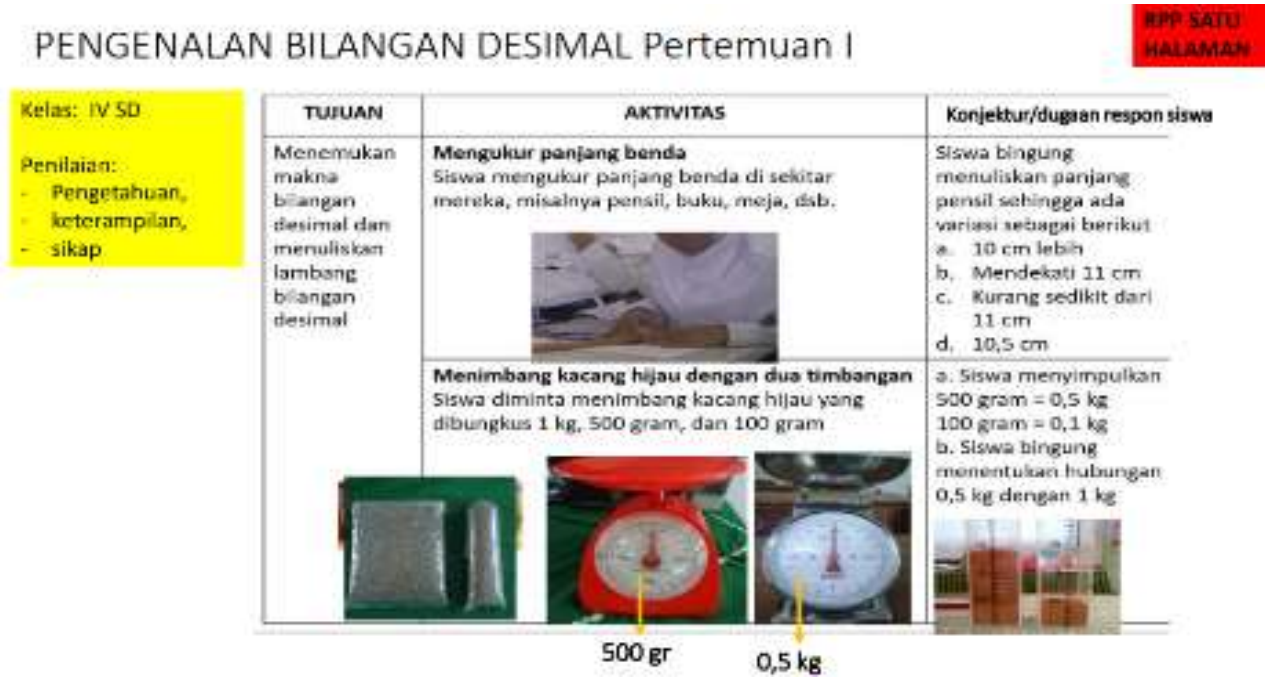

Gambar 3: contoh RPP satu halaman mata pelajaran matematika (Sumber: Johar, R., 2020) 
Technological Content Knowledge merupakan pengetahuan tentang hubungan antara materi pelajaran dan teknologi, termasuk pengetahuan teknologi. Misalkan seorang guru matematika ketika ingin mengajarkan materi geometri, apakah guru tersebut dapat merepresentasikan pengetahuan geometri yang dimilikinya melalui penggunaan teknologi, dalam membuat bagan, garis, maupun sudut. Guru matematika tidak hanya mentransfer ilmu materi yang dimilikinya, namun dapat mengaplikasikannya dengan menggunakan digital dalam pembelajaran. Berikut contoh software yang harus dikuasai guru, yang ditampilkan oleh gambar 4.

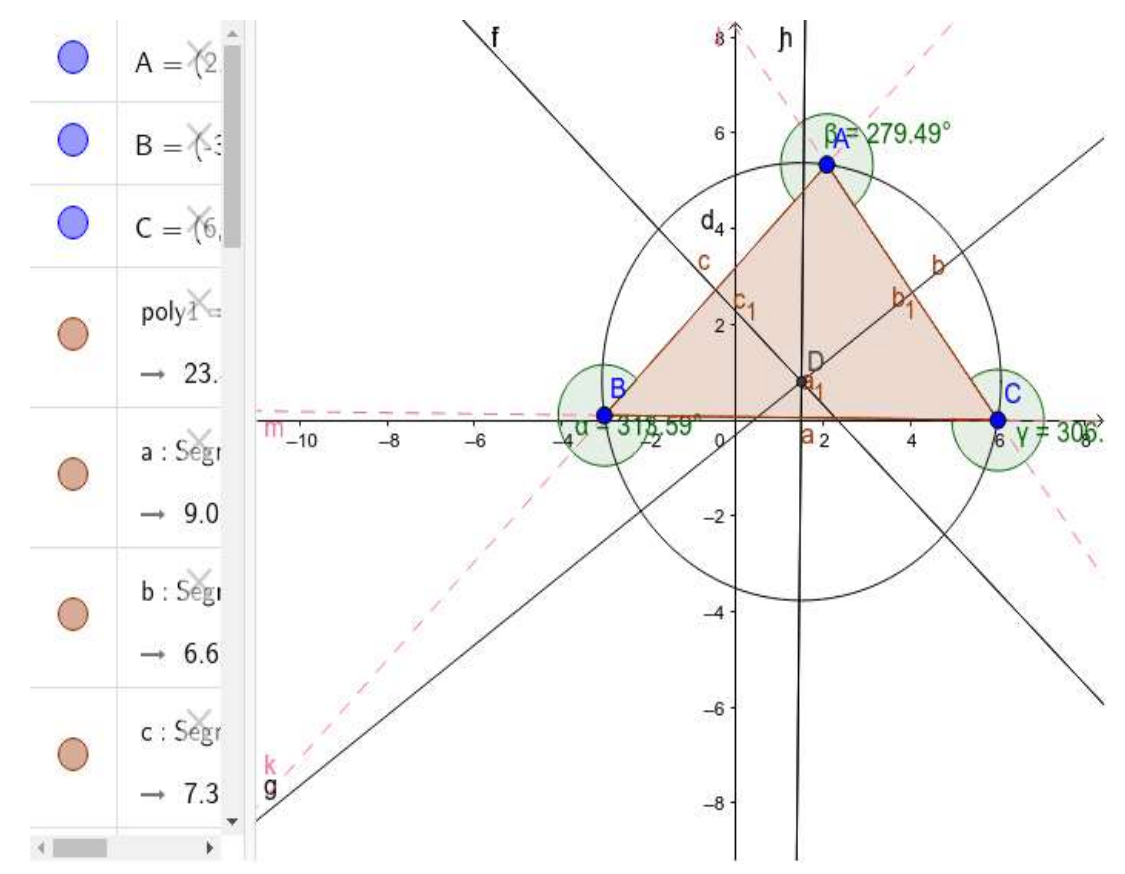

Gambar 4: contoh project geogebra (sumber: https://www.geogebra.org/m/xfHh8Mnb)

Technological Pedagogical Knowledge pengetahuan tentang pengaruh teknologi pada pengajaran dan pembelajaran, guru harus mampu mendesain serta memperhitungkan teknologi apa yang sekiranya dapat mendukung pembelajaran dengan baik, sehingga tujuan pedagogic tercapai, dari teknologi juga guru diharapkan dapat membuat metode pembelajaran, misalnya dengan pembelajaran online, di masa pandemik ini, guru sangat dituntut kreativitas variasi mengajar dengan menggunakan teknologi, sekarang banyak digunakan beberapa aplikasi yang muncul dengan adanya pembelajarn jarak jauh, guru harus menguasai berbagai aplikasi untuk mengajar Pembelajaran Jarak Jauh (PJJ). Berikut gambar beberapa aplikasi yang selayaknya dikuasai oleh guru. 


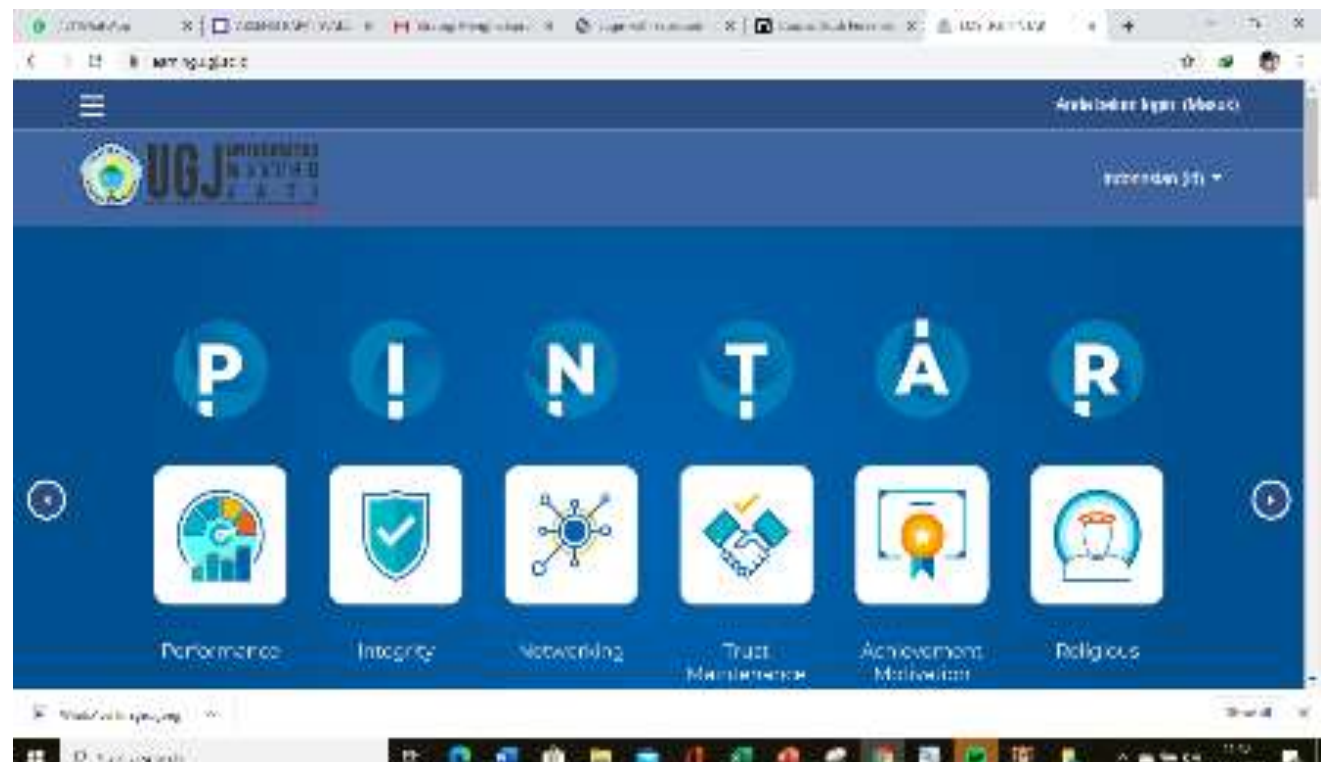

Gambar 5: Contoh aplikasi Learning Manajement System

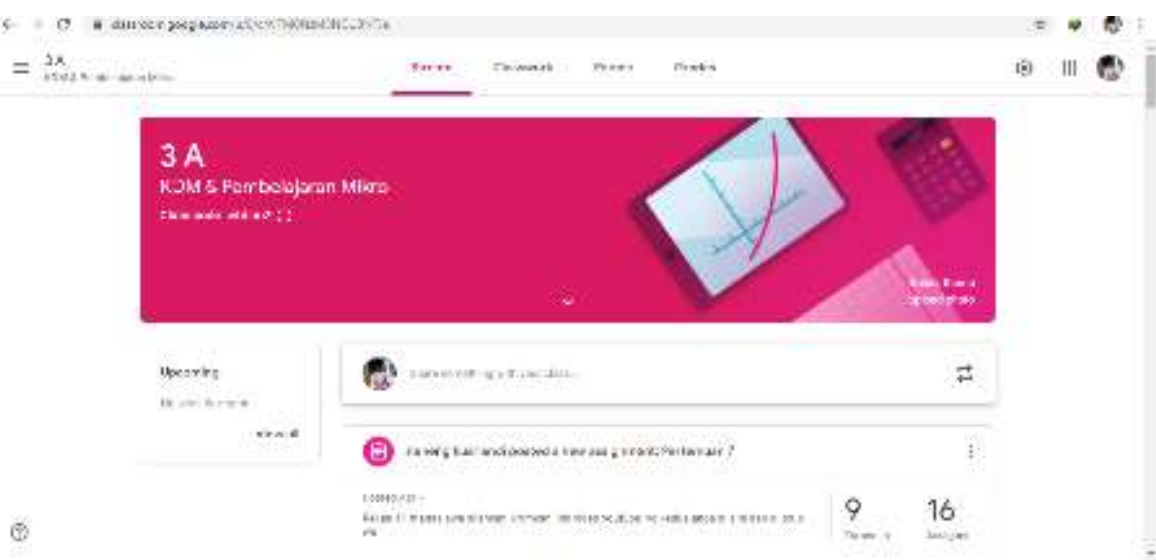

Gambar 6: contoh aplikasi google classroom

Technological Pedagogical Content Knowledge mendeskripsikan yang semuanya tercangkup kedalam pengetahuan ini, seorang guru diharapkan mampu untuk dapat menyatukan kemampuan Technological Knowledge, Content Knowledge, Pedagogical Knowledge, Pedagogical Content Knowledge, Technological Content Knowledge, dan Technological Pedagogical Knowledge, menjadi satu kesatuan yang utuh yang dituangkan kedalam desain mengajar untuk mencapai tujuan pembelajaran yang efektif.

\section{KESIMPULAN}

Pendidikan sangat membutuhkan peranan dari segenap unsur baik guru, orang tua, murid, sekolah, maupun pemerintah, namun dari pembahasan diatas peran guru sangat dominan, sehingga sangat diharapkan guru memberikan kontribusi yang besar dalam membangun peserta didik saat di sekolah. Teknologi yang sedang marak merupakan salah 
satu probematika yang terjadi, dari data litelature TPACK yang telah dibahas diatas dapat digunakan sebagai acuan guru dalam meningkatkan profesionalismenya, dan uraian diatas bisa sebagai acuan teori untuk membuat instrumen penelitian mengukur TPACK.

\section{DAFTAR PUSTAKA}

Aminah, N. and Wahyuni, I. (2018). Design of Capability Measurement Instruments Pedagogic Content Knowledge (PCK) for Prospective Mathematics Teachers. J.Phys.:Conf.Ser.1013 012112. online : http://iopscience.iop.org/issue/1742$\underline{6596 / 1013 / 1}$

Aminah, N \& Wahyuni I, (2018) Kemampuan Pedagogic Content Knowledge (PCK) Calon Guru Matematika Pada Program Pengalaman Lapangan di SMP/SMA Negeri Kota Cirebon JNPM (Jurnal Nasional Pendidikan Matematika), September 2018 Vol. 2, No. 2, Hal. 25.

Angeli, C., \& Valanides, N. (2005). Preservice teachers as ICT designers: An instructional design model based on an expanded view of pedagogical content knowledge. Journal of ComputerAssisted Learning, 21(4), 292-302

Atack, L. (2003). Becoming a Web-based learner: Registered nurses_experiences. Journal of Advanced Nursing, 44, 289Y297

Chai C-S, Koh JH-L, Tsai C-C (2013) A review of technological pedagogical content knowledge. Educational Technology \& Society 16(2):31-51

Direktorat Pembinaan SMA. 2008. Panduan Pengembangan Bahan Ajar, Jakarta: Departemen Pendidikan Nasional

Fathurrohman M, Porter A L, and Worthy A L (2017) Teachers' real and perceived of ICT supported-situation for mathematics teaching and learning International Journal on Emerging Mathematics Education p. 111

Jimoyiannis, A. and Komis, V. (2007), "Examining teachers' beliefs about ICT in education: implications of a teacher preparation programme”, Teacher Development, Vol. 11 No. 2, pp. 149-73.

Johar, R. (2020). Rancangan Pelaksanaan Pembelajaran (RPP) satu halaman berbasis $R M E$. Diseminarkan pada kegiatan Webinar Kerjasama PPPMI dengan Pascasarjana UNNES Rabu, 2 Juni 2020.

Korhonen, T., \& Lammintakanen, J. (2005). Web-based learning in professional development: Experiences of Finnish nurse managers. Journal of Nursing Management, 13, 500Y507.

Ministry of Education and Culture (2010), Information Society Development in Education 2020. Better quality, more effective co-operation and transparent interaction), Ministry of Education and Culture, available at: www.minedu.fi/ (accessed January 2012).

Mishra, P., \& Koehler, M. J. (2006). Technological Pedagogical Content Knowledge: A framework for teacher knowledge. Teachers College Record, 108(6), 1017-1054

Muhtadi D, wahyudin, dkk. (2017). The Integration of Technologi in Teaching Mathematics. IOP Conf. Series: Journal of Physics: Conf. Series 94301202.

National Centre For Competency Based Training. (2007). Pengertian Bahan Ajar. http:www.kajianteori.com/2014/02/pengertian- bahan-ajar. html

Niess, M. (2008a). Mathematics teachers developing technology, pedagogy and content Knowledge (TPACK). In K. McFerrin et al. (Eds.), Proceedings of Society for Information Technology \& Teacher Education International Conference 2008 (pp. 5297-5304). Chesapeake, VA: AACE. 
Niess, M. L. (2008b). Knowledge needed for teaching with technologies - Call it TPACK. AMTE Connections, 17(2), 9-10

Niess ML, Ronau RN, Shafer KG, Driskell SO, Harper SR, JohnstonC, Browning C, O “ zgu "n-Koca SA, Kersaint G (2009) Mathematics teacher TPACK standards and development model. Contemp Issues Technol Teacher Educ 9(1):4-2

Noortje Janssen1 • Ard W. Lazonder, (2015), Implementing Innovative Technologies Through Lesson Plans: What Kind of Support Do Teachers Prefer? J Sci Educ Technol , 4:910-920

Pierce, R., \& Ball, L. (2009). Perceptions that may affect teachers' intention to use technology in secondary mathematics classes. Educational Studies in Mathematics, 71(3), 299-317.

S.N. Kushner Benson et al., (2015), The Essential Role of Pedagogical Knowledge in Technology Integration for Transformative Teaching and Learning, Handbook of technological pedagogical and content knowledge for educators. Routledge, New York, NY, p 3-18.

S. Supangat, (2018). Pemahaman Guru Tentang Teknologi Informasi (Studi Kasus Guru di SD Dan SMP Sekolah Shafta Surabaya). Seminar Nasional Untag Jakarta.p. 458-468.

Syukur, I.A. (2014). Profesionalisme Guru dalam Mengimplementasikan Teknologi Informasi dan Komunikasi di Kabupaten Nganjuk. Jurnal Kemendikbud Vol 2 No 2 p. 200-210

Tanujaya B, Prahmana R C I, and Mumu J (2017) Mathematics instruction, problems, challenges, and opportunities: A case study in Manokwari regency, Indonesia World Transactions on Engineering and Technology Education 15287

Thompson, A. D., \& Mishra, P. (2007). Breaking news: TPCK becomes TPACK! Journal of Computing in Teacher Education, 24(38), 64

Torff, B., \& Tirotta, R. (2010). Interactive whiteboards produce small gains in elementary students' self-reported motivation in mathematics. Computers \& Education, 54(2), 379-383. doi:10.1016/j.compedu.2009.08.019

Voogt J, Fisser P, Tondeur J, van Braak J (2016) Using theoretical perspectives in developing understanding of TPACK. In: Heering MC, Koehler MJ, Mishra P (eds) Handbook of technological pedagogical and content knowledge for educators. Routledge, New York, NY, p 33e52. 
